Meta

Journal des traducteurs

Translators' Journal

\title{
Power, Identity and Subtitling in a Diglossic Society
}

\section{Wai-Ping Yau}

Volume 57, numéro 3, septembre 2012

URI : https://id.erudit.org/iderudit/1017080ar

DOI : https://doi.org/10.7202/1017080ar

Aller au sommaire du numéro

\section{Éditeur(s)}

Les Presses de l’Université de Montréal

ISSN

0026-0452 (imprimé)

1492-1421 (numérique)

Découvrir la revue

Citer cet article

Yau, W.-P. (2012). Power, Identity and Subtitling in a Diglossic Society. Meta, 57(3), 564-573. https://doi.org/10.7202/1017080ar

\section{Résumé de l'article}

Le présent article tente de répondre à la problématique de l'identité et des relations de pouvoir qui se présentent dans la pratique du sous-titrage. Plus précisément, l'article se penche sur la manière dont le sous-titrage peut jouer un rôle actif dans le façonnement de l'identité par la médiation entre le local, le national et le global, ainsi que sur la façon dont le sous-titreur peut jouer un rôle dans la régulation des relations de pouvoir entre les secteurs culturels. Ces questions sont examinées dans le contexte d'une société diglossique, non seulement parce que les questions sur la langue, l'identité et les relations de pouvoir sont intimement impliquées dans les discussions sur la diglossie, mais aussi parce que celle-ci est une expérience commune pour de nombreux sous-titreurs et les publics du cinéma. L'auteur explore l'hypothèse que le sous-titreur peut créer une langue hybride qui redéfinit les rôles rigides assignés au dialecte local et à la langue nationale et qui modifie les codes de lecture des sous-titres. Des exemples provenant de Hong Kong sont utilisés à titre d'illustration.
Ce document est protégé par la loi sur le droit d'auteur. L'utilisation des services d'Érudit (y compris la reproduction) est assujettie à sa politique d'utilisation que vous pouvez consulter en ligne.

https://apropos.erudit.org/fr/usagers/politique-dutilisation/ 


\title{
Power, Identity and Subtitling in a Diglossic Society
}

\author{
WAI-PING YAU \\ Hong Kong Baptist University, Hong Kong \\ wpyau@hkbu.edu.hk
}

\begin{abstract}
RÉSUMÉ
Le présent article tente de répondre à la problématique de l'identité et des relations de pouvoir qui se présentent dans la pratique du sous-titrage. Plus précisément, l'article se penche sur la manière dont le sous-titrage peut jouer un rôle actif dans le façonnement de l'identité par la médiation entre le local, le national et le global, ainsi que sur la façon dont le sous-titreur peut jouer un rôle dans la régulation des relations de pouvoir entre les secteurs culturels. Ces questions sont examinées dans le contexte d'une société diglossique, non seulement parce que les questions sur la langue, l'identité et les relations de pouvoir sont intimement impliquées dans les discussions sur la diglossie, mais aussi parce que celle-ci est une expérience commune pour de nombreux sous-titreurs et les publics du cinéma. L'auteur explore l'hypothèse que le sous-titreur peut créer une langue hybride qui redéfinit les rôles rigides assignés au dialecte local et à la langue nationale et qui modifie les codes de lecture des sous-titres. Des exemples provenant de Hong Kong sont utilisés à titre d'illustration.
\end{abstract}

\begin{abstract}
This article attempts to address the problematics of identity and power relations as they arise in the practice of subtitling. Specifically, the article asks questions about how subtitling can play an active part in the shaping of identity by mediating between the local, the national and the global, and how the subtitler can be an agent in adjusting the power relations between cultural constituencies. These questions are considered in the context of a diglossic society, not only because issues about language, identity and power relations are inextricably involved in discussions about diglossia, but also because diglossia is a common experience for many subtitlers and film audiences. The possibility is explored that the subtitler can create a hybrid language that redefines the rigid roles assigned to the local dialect and the national language and revises our codes for reading subtitles. Examples from Hong Kong are used to illustrate these points.
\end{abstract}

\section{MOTS-CLÉS/KEYWORDS}

traduction audiovisuelle, dialecte, diglossie, sous-titrage, Hong Kong audiovisual translation, dialect, diglossia, subtitling, Hong Kong

\section{Introduction}

Debate about the relative merits and demerits of dubbing and subtitling has been characterized by a polarization of perception: on the one hand, dubbing yields readily to domestication and ideological manipulation (along nationalist lines, for example) because the original dialogue is removed; on the other, subtitling is essentially foreignizing because the original dialogue remains accessible to the target audience (see, for example, Danan 1991; Mera 1999; Gutiérrez Lanza 1997; Szarkowska 2005). Despite attempts to dissolve the dichotomy between domestication and for- 
eignization (see, for example, Martí Ferriol 2010), this polarization has persisted and proved less than helpful in addressing the problematics of identity and power relations as they arise in the practice of subtitling considered within local, national and global contexts. Questions have rarely been asked about how subtitling can play an active part in the shaping of identity by mediating between the local, the national and the global, and how the subtitler can be an active agent in adjusting the power relations between cultural constituencies. ${ }^{1}$ As my title suggests, I want to pursue this line of questioning by relating the subtitler's use of language to issues about identity and power relations in the context of a diglossic society, not only because questions about language, identity and power relations will inevitably come up in discussion about diglossia, but also because diglossia, which can exist in local, national and international contexts, is a relevant experience for many subtitlers and film audiences. I will use examples from Hong Kong to illustrate these points.

Hong Kong can be said to be a diglossic society in the sense used by Ferguson (1959: 336), where the national language (Standard Chinese) as a high $(\mathrm{H})$ variety is used for serious written communication, and the local dialect (Cantonese) as a low (L) variety is used for daily conversation and informal written communication. Whereas Standard Chinese connotes "the national, the educated, the elevated, and the cultured" (Gunn 2006: 4), Cantonese carries low prestige. The relative social status of Cantonese and Standard Chinese has a direct bearing on the construction of identity in the practice of subtitling in Hong Kong (see Yau (2010: 109) for further discussion about Hong Kong as a diglossic society).

\section{The use of dialect for a low register}

In Hong Kong, foreign films have traditionally been subtitled and translated into Standard Chinese. But a trend since the early 1990s has been for subtitlers to use Cantonese to translate colloquialisms, slang terms, swear words, and sexually explicit or suggestive language in foreign films intended for entertainment, e.g. comedy, romance and action. Critics have stressed that this use of written Cantonese for a low register serves to bridge the gap between spoken and written language (Putonghua, or the spoken counterpart of Standard Chinese, is learnt as a second language by most Hong Kong people), to create an equivalent effect, and to make the subtitles more transparent, readily intelligible, familiar and relevant to local viewers (Lo 2001, Fong 2001, ${ }^{2}$ Shu Kei 2001, ${ }^{3}$ Chen 2004). A strong advocate of Cantonese subtitles, Chen (2004: 137-138) argues that swear words should be translated into "Cantonese equivalents" because "they convey the original spirit most effectively and arouse the greatest empathy on the part of the Hong Kong audience, who are mostly native speakers of Cantonese." To counteract the deep prejudice against written Cantonese, Chen has compiled a table of conversion between common English swear words and Cantonese terms and issued a call to arms: "Hong Kong people should struggle for the right to see the original features of English swearwords revived in the subtitles" through the use of written Cantonese (Chen 2004: 138, 143-147).

But such an attempt to assert an identity for the people of Hong Kong is problematic because written Cantonese is confined to the linguistic ghetto of low register. This in fact reinforces the social stigma attached to written Cantonese, solidifies traditional stereotypes, and confirms the dichotomy between Standard Chinese and 
written Cantonese. Furthermore, the foreign is domesticated through an illusion of transparency and immediate access to the original, while the assumption of equivalent effect is left unchallenged. A case in point is the 2004 British film 9 Songs, ${ }^{4}$ directed by Michael Winterbottom, screened at the 2005 Hong Kong International Film Festival and subsequently released on video compact disc (VCD) with Chinese subtitles. The film, set in London, tells of the love story of Matt, a British glaciologist, and Lisa, an American exchange student. Framed by Matt's reminiscences, the film depicts scenes of unsimulated sex, interspersed with footage of nine songs performed by the couple's favourite rock bands. In the title sequence, a scene showing Matt working in Antarctica cuts to a sex scene between the couple, as the voice of Matt reminisces about Lisa:

(1a) Matt: When I remember Lisa, I don't think about her clothes... / ...or her work, where she was from, or even what she said. / I think about her smell, her taste. / Her skin touching mine.

(9 Songs 2004)

The informal language - stylistically marked by the use of contraction, relatively simple sentences, loosely connected phrases, as well as simple everyday vocabulary - is translated into colloquial Cantonese:

(1b) Matt: 諗起麗莎, 我唔會諗佢著咩衫/ 亦諗唔起佢邊度嚟或講過七嘢 / 我淨係 記得佢的氣味/ 我同佢既肌膚接觸. (Cantonese)

[When I think about Lisa, I don't think about her clothes, / where she was from or what she said. / All I remember is her smell, her taste, / my skin touching hers.]

(情慾9歌 [9 Songs of Lust and Passion] 2005; back-translated by the author)

Later in the film the subtitler also uses Cantonese to translate the dialogue between Lisa and Matt, including swear words and sexually explicit or suggestive expressions:

(2a) Lisa: I wanna bite your lip really fucking hard and make you bleed

(9 Songs 2004)

(2b) Lisa： 想咬Q到你個咀唇爆缸個隻. ${ }^{5}$ (Cantonese)

[I wanna bite your lip so fucking hard it bleeds.]

(情慾9歌 [9 Songs of Lust and Passion] 2005; back-translated by the author)

But the subtitler switches to Standard Chinese whenever lyrics are subtitled on the screen. Take, for instance, the first song Whatever Happened to my Rock'n'Roll, which comes immediately after the title sequence. This song is performed on stage by the Black Rebel Motorcycle Club at the Brixton Academy, and footage of the performance is punctuated by several shots of sex between the couple. The language of the lyrics is informal, with colloquialisms and relatively short and simple sentences:

(3a) You want a part of me

You want the whole thing

You want to feel something more than I could ever bring

You want it badly. You want it tangled

I want to feel something more than I was strangled 
I fell in love with the sweet sensation

I gave my heart to a simple chord

I gave my soul to a new religion.

(9 Songs 2004)

But rather than sticking to the use of written Cantonese, the subtitler chooses to translate the lyrics into Standard Chinese:

(3b) 你要我的一部分 / (Standard Chinese)

[You want a part of me /]

你要我的一切 /

[You want everything that belongs to me /]

連我給不到你的都要 /

[You want more than I couldn't bring you /]

你是那麼渴求與糺纏 /

[You desire so strongly, you get so entangled /]

令我窒息也充滿快感 /

[I'm suffocated but also ecstatic /]

我已愛上這感覺 /

[I've fallen in love with this feeling /]

為我的心譜上和絃/

[It struck a chord with my heart /]

讓我的靈魂獻給新宗教 (Standard Chinese)

[Let me give my soul to a new religion]

(情慾9歌 [9 Songs of Lust and Passion] 2005; back-translated by the author)

In other words, Standard Chinese is reserved for a public form of communication such as lyrics of songs performed by established music groups, whereas the low register of everyday language is rendered into Cantonese. Despite its increased visibility, the use of written Cantonese in this film in fact perpetuates the prejudice that Cantonese is vulgar and unsuitable for "serious" communication. As a film released internationally, 9 Songs is mediated through a binary opposition between the local dialect and the national language. The subtitler's translation strategy constructs a local identity that reinforces the rigid boundaries between the $\mathrm{H}$ and the $\mathrm{L}$ variety, and the asymmetrical power relations inscribed in this dichotomy remains unaltered.

A related problem is the use of Cantonese subtitles for sociolect in film, because register, as language variation defined by use, often overlaps with varieties defined by the user's social background. Lo (2001: 51-57) faults the subtitled version of George Cukor's 1964 film My Fair Lady for failing to use Cantonese to translate the Cockney English spoken by the flower girl Eliza Doolittle. In the film Eliza is trained by the phonetics professor Henry Higgins to "correct" her Cockney English and speak with an upper class accent. It is argued here that to translate Cockney English into Cantonese in this case is to treat Cantonese as inferior, deficient, ungrammatical - in other words, as bad Chinese. This will only perpetuate the social stigma attached to written Cantonese. 


\section{The use of dialect in a subcultural context}

If it is problematic for the subtitler to limit the use of dialect to a low register, can dialect be put to good use as a means of stressing the subcultural status of a marginal group? Let us consider the case of 8 Mile, a 2002 American film directed by Curtis Hanson $^{7}$. Set in Detroit, Michigan in 1995, the film follows the aspiring rap artist Jimmy "B Rabbit” Smith Jr (Marshall "Eminem" Mathers) as he struggles to launch his musical career. In the subtitled version released on VCD in Hong Kong, Cantonese is used to translate all the dialogue, as well as all the rap lyrics. The climax of the film comes with a rap battle in which Rabbit confronts "Papa Doc" - the best rapper of the black group "Leaders of the Free World" - with the latter's attempt to hide his more privileged background (Papa Doc attends a private school). Rabbit's freestyle rap proudly acknowledges his "white trash" origins:

(4a) I know everything he's got to say against me

I am white, I am a fuckin bum, vere

I do live in a trailer with my mom

My boy Future is an Uncle Tom

I do got a dumb friend named Cheddar Bob

who shoots himself in the leg with his own gun

I did get jumped by all six of you chumps

And Wink did fuck my girl

I'm still standin here screamin "Fuck the Free World!"

Don't ever try to judge me dude

You don't know what the fuck I've been through

[...]

I'm a piece of fuckin white trash, I say it proudly

(8 Mile 2002)

This rap allows Rabbit to articulate clearly and communicate publicly a sense of self that is firmly grounded on the recognition with dignity of one's social background and ethnic origins ( $\mathrm{am}$ white, I am a fuckin bum, I do live in a trailer with my mom, I'm a piece of fuckin white trash, I say it proudly). This rap is not only an expression of oppression (You don't know what the fuck I've been through) but also an act of self-assertion (I'm still standin here screamin) and protest (Don't ever try to judge me dude). Embedded in the underclass subculture of Detroit, this rap expresses not just rage but also empowerment against marginality and stigmatization. Here are the Cantonese subtitles:

(4b) 我知佢有惡意/

[I know he's against me /]

唱我皮白 / 唱我賤格 /

[He says I'm white / he says I'm cheap /]

我的確靠阿媽 / 以拖車為家 /

[I do live in a trailer / and depend on my mom /]

未來係我老死 / 專受白人氣 /

[Future is my best buddy / and whites treat him like shit /]

傯佬財係老友記 / 開槍射自己 /

[My friend Cheddar is so dumb / he shoots himself with his gun /]

我曾經俾你地隊 /

[I did get beaten up by you guys /] 


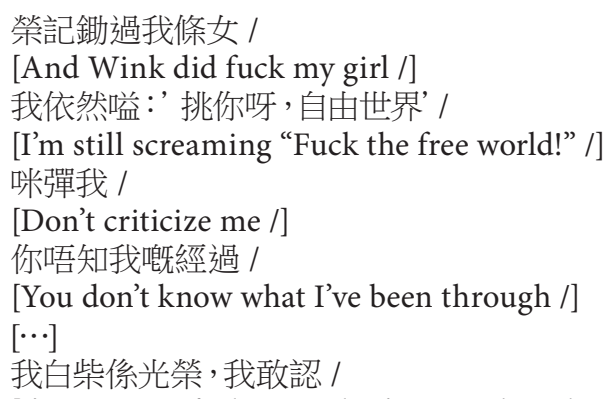

The subtitler has skilfully created an intricate pattern of rhymes and a staccato rhythm with a series of short, sharp, separate sentences. The angry, defiant lyrics are rendered with a locally marked vocabulary of colloquialisms, slang terms and swear words. Here the use of Cantonese subtitles stresses a sense of alienation from the dominant culture, underlines rap as a form of articulating identity against a specific social background, and at the same time calls attention to the status of Cantonese as a marginalised discourse. As a musical genre, rap has travelled across languages and cultures to become a major mode of the global popular culture, often through audiovisual products such as films and music videos released internationally. In 8 Mile, rap retains an awareness of its origins in specific social situations and reminds audiences about who the rappers are and what is happening to them, and examines "the 'real' in relation to regional and local identities" (Morgan 2001: 189). By using Cantonese to translate the rap lyrics and the dialogue of the underclass in 8 Mile, the subtitler alerts viewers to the specific, the local and the political in this globalized product and proclaims Cantonese as an effective vehicle for counteracting stigmatization.

\section{Subtitles as a "literary" language}

If the subtitler can use dialect in a subcultural context as an effective strategy for self-assertion against marginalization, perhaps a case can be made for dialect to serve as the language of identity for the local community. Perhaps Cantonese subtitles can break through traditional barriers to become a symbolic expression of a unique Hong Kong identity (in this connection the subtitling strategy for 8 Mile stays within the generic limits on account of its youthful target audience and its association with oral performance). This appears to be an attractive approach insofar as the subtitler can take advantage of the full range of the linguistic registers available in Cantonese to render the vulgar as well as the sublime. The use of authentically transcribed Cantonese will also close the gap between spoken and written language lamented by advocates of Chinese subtitles. But such an approach is not without its problems. For one thing, the national language is denied any role in the shaping of identity for the local community. For another, the authentic transcription of the local dialect proposes a perfect fit between a variety of language and a way of life - an ideal embodied in the slogan “我手寫我 $\square$ ” which Snow (2004: 37) translates as “My hand writes as my mouth speaks") - and encourages a mimetic view of language, i.e. language 
passively reflects like a mirror a fixed entity or pre-existing experience, rather than actively producing a sense of our identity.

If language is the means through which identity is constructed, is it possible for the subtitler to create a hybrid language that refuses the relegation of the local dialect to the linguistic ghetto of low register, adapts the national language to the local culture, and dissolves the dichotomy between the standard and the non-standard variety? Is it possible for the subtitler to fashion a written form that incorporates the rich resources of orality? Is it possible for the subtitler to use language in such a way as to signal a difference from the dominant forms of cultural representation? Let us consider Woody Allen's 2005 film Match Point, ${ }^{8}$ released on DVD in Hong Kong in 2006, with Chinese subtitles by Michael Lam. The protagonist Chris Wilton finds himself torn between, on the one hand, his ambition to climb the social ladder through marriage to the daughter of a wealthy man and, on the other, his desire for the beautiful woman Nola Rice. When Nola becomes pregnant and threatens to reveal their relationship to his wife, Chris decides she must die. Chris kills Nola, but not before he kills her elderly neighbour in order to make them look like random victims of a robber. Chris literally gets away with murder, only to find himself haunted by his victims. Towards the end of the film, Chris is visited by two ghostly apparitions in the middle of the night:

(5) Nola:

Chris:

Neighbour:

Chris:

Neighbour:

\section{Chris}

基斯. (Cantonese)

[Chris.]

Nola. It wasn't easy. When the time came, I couldn't pull the trigger. You never know who your neighbours are till this crisis. You can learn to push your guilt under the rug... and go on. You have to. Otherwise, it overwhelms you.

奴娜 / 不容易呀 / 事到臨頭唯有咬緊牙關 / 不到臨危時不會認識 鄰居/總要學會埋沒良心活下去 /一定要這樣/否則永不翻身

[Nola / It wasn't easy / When things come to a head, you just grit your teeth and get on with it / You never know who your neighbours are till you face a crisis / In the end you have to learn to bury your conscience and go on living / You have to / Otherwise, you will never get yourself back on your feet again]

What about me? What about the next door neighbour? I had no involvement in this awful affair. Is it no problem about me having to die as an innocent bystander?

那麼我呢? / 爲何鄰居被率連? / 我與這宗醜事完全無關 / 無辜 辜 [wugugu] 被殺, 説得過去嗎?

[What about me? / Why drag a neighbour into this? / I had nothing to do with this shameful thing / An innocent killed. Justified?]

The innocent are sometimes slain to make way for grander schemes. You were collateral damage.

無享者有時要壯烈犧牲 / 你是無可避免的祭品

[The innocent sometimes have to make the supreme sacrifice / You were an unavoidable sacrifice]

So was your own child?

未出世的孩子也是

[So was the unborn child] 
Chris: $\quad$ Sophocles said, 'To never have been born may be the greatest boon of all.'

詩人索福克勒斯說：/ 從未誕生 / 可能是最大的福氣

[The poet Sophocles said: / To never have been born / may be the greatest blessing]

Nola: $\quad$ Prepare to pay the price, Chris. Your actions were clumsy. Full of holes. Almost like someone begging to be found out..

冤有頭債有主，基斯 / 你雞手鴨腳 [ji shou ya jiao] / 漏洞百出 / 幾 乎路人皆見

[Prepare to pay your debts when due, Chris / You were so clumsy / Full of holes / Almost anyone can see it]

Chris: It would be fitting if I were apprehended....and punished. At least there would be some small sign of justice - some small measure of hope for the possibility of meaning.

如果我被揭發是罪有應得 / 證明還有點公道 / 小小的... / ...合乎 情理的希望

[If I were found out, it would be a fitting punishment for my crimes / It would prove that there's still justice / a tiny bit of... / ... reasonable hope]

Here the subtitler creates a coherent pattern of condensed sentences by using many set phrases shared by both Cantonese and Standard Chinese (e.g. 事到臨頭 [things come to a head], 咬緊牙關 [ grit your teeth and get on with it], 埋沒良心 [bury your conscience], 永不翻身 [you will never get yourself back on your feet again], 壯烈 犧牲 [make the supreme sacrifice], 無可避免 [unavoidable], 罪有應得 [a fitting punishment for my crimes]). Colloquial expressions in Standard Chinese are used strategically to stress first Chris's lame defence (不容易呀 [It wasn't easy]), then the challenge to Chris's logic (那麼我呢? [What about me?]), and finally the rhetorical question 説得過去嗎? (Justified?). But formal expressions, spoken perhaps only in oral performance such as traditional Chinese opera, are used for compression (爲 何...? [Why...]) and for emphasis (無辜者 [The innocent]). Significantly, two specifically Cantonese expressions are used. First, 無鼓喜 (wugugu) - formed by repeating the second syllable in the word for innocent in Standard Chinese - introduces into the text the oral rhythm of spoken Cantonese. Second, 雞手鴨腳 (ji shou ya jiao) is used to describe Chris's clumsy actions. The intelligibility of this Cantonese expression is enhanced by its insertion between the subject 你 (you) and the complement formed by two set phrases shared by both Cantonese and Standard Chinese (漏洞百 出/ [Full of holes], 路人皆見 [Almost anyone can see it]). And this follows logically from the common Chinese proverbial saying “冤有頭債有主” (“Prepare to pay your debts when due"). In this scene the subtitler has created a composite language through a combination of Cantonese and Standard Chinese expressions. This "artificial" language is different from spoken Cantonese, Putonghua or Standard Chinese, and yet remains accessible. This can be considered as "literary" language to the extent that it draws attention to its style in addition to communicating the content of the dialogue. This use of language asserts a cultural identity that taps into the resources of both the local and the national, without falling into the trap of the old dichotomy. 


\section{Conclusion}

As globalized products, films released internationally are often mediated through the local dialect and the national language as options open to the subtitler. While restricting the use of the local dialect to a low register may reinforce the asymmetrical power relations embedded in the dichotomy between the $\mathrm{H}$ and $\mathrm{L}$ variety in a diglossic society, the use of the local dialect in a subcultural context can be an act of selfassertion against its cultural marginality. But the use of the local dialect as the language of identity, to the exclusion of the national language, may encourage a mimetic view of language that obscures the productive role of language in the construction of identity. The possibility is entertained here that the subtitler can play an active part in the shaping of identity by creating a hybrid language that subverts the hierarchy of the $\mathrm{H}$ and the $\mathrm{L}$ variety. Without ceasing to be intelligible and relevant to the original, the subtitles draw upon the standard and the non-standard, the spoken and the written, the current and the archaic, and in this way acquire a thickness that is not quite opacity. This hybrid language interrogates the categories that consign a local dialect to a linguistic ghetto, and proposes new codes for reading subtitles. It invites the audience to read subtitles not mimetically as a transparent medium, but rather rhetorically as textual practice that provides possibilities for the shaping of identity and points to the potential of the subtitler as an active agent in altering the power relations inscribed in cultural representations.

\section{NOTES}

1. See Hatim and Mason (1997, chapter 5) for an early attempt to address the issue of power relations in subtitling through pragmatics, in particular with reference to "politeness," i.e. "aspects of language usage which serve to establish, maintain or modify interpersonal relationships between text producer and text receiver" (80).

2. FonG, Gilbert C. F. (2001): The Two Worlds of Subtitling: The Case of Vulgarisms and Sexually Oriented Language. Paper presented at the International Conference on Dubbing and Subtitling, unpublished. Hong Kong: Chinese University of Hong Kong.

3. Shu KeI (2001): Translating Subtitles for the Hong Kong Audience: Limitations and Difficulties. Paper presented at the International Conference on Dubbing and Subtitling, unpublished. Hong Kong: Chinese University of Hong Kong.

4. 9 Songs (2004): Directed by Michael Winterbottom. United-Kingdom.

情慾9歌 [9 Songs of Lust and Passion] (2005): Hong Kong subtitled version of 9 Songs (2004).

5. Romanization is used by the subtitler for the Cantonese translation of fucking because no appropriate character from Standard Chinese is available for borrowing.

6. My Fair Lady (1964): Directed by George Cukor. United-States. 窈花淑女 [Fair Lady] (n.d.): Hong Kong subtitled version of My Fair Lady (1964).

7. 8 Mile (2002): Directed by Curtis Hanson. United-States. 8里公路 [8 Mile Highway] (2003): Hong Kong subtitled version of 8 Mile (2002).

8. Match Point (2005): Directed by Woody Allen. United-States. 迷失決勝分 [At a Loss about Match Point] (2006): Hong Kong subtitled version of Match Point (2005).

\section{REFERENCES}

Chen, Chapman (2004): On the Hong Kong Chinese Subtitling of English Swearwords. Meta. 49(1):135-147.

Danan, Martine (1991): Dubbing as an Expression of Nationalism. Meta. 36(4):606-614.

Ferguson, Charles A. (1959): Diglossia. Word. 15:324-340. 
Gunn, Edward (2006): Rendering the Regional: Local Language in Contemporary Chinese Media. Honolulu: University of Hawai'i Press.

Gutiér rez Lanza, Maria Del Camino (1997): Spanish Film Translation: Ideology, Censorship, and the Supremacy of the National Language. In: Marian B. Labrum, ed. The Changing Scene in World Languages: Issues and Challenges. Amsterdam/Philadelphia: John Benjamins, 35-45.

Hatim, Basil and Mason, Ian (1997): The Translator as Communicator. London: Routledge.

Lo, Wai Yan (2001): Film Translation in Hong Kong: Cantonese Subtitles and Transparency. Master dissertation, unpublished. Hong Kong: Chinese University of Hong Kong.

Martí Ferriol, José Luis (2010): Cine independiente y traducción. Valencia: Librería Tirant lo Blanch.

Mera, Miguel (1999): Read My Lips: Re-evaluating Subtitling and Dubbing in Europe. Links \& Letters. 6:73-85.

Morgan, Marcyliena (2001): 'Nuthin' but a G thang': Grammar and Language Ideology in Hip Hop Identity. In: Sonja L. LANEHART, ed. Sociocultural and Historical Contexts of African American English. Amsterdam/Philadelphia: John Benjamins, 187-209.

Snow, Don (2004): Cantonese as Written Language: The Growth of a Written Chinese Vernacular. Hong Kong: Hong Kong University Press.

Szarkowska, Agnieszka (2005): The Power of Film Translation. Translation Journal 9(2). Visited on 12 March 2012, <http://www.bokorlang.com/journal/32film.htm>.

YAU, Wai-ping (2010): Translating Audiovisual Humour: A Hong Kong Case Study. In: Delia Chiaro, ed. Translation, Humour and the Media. London: Continuum, 108-120. 